\title{
Old Wine in New Bottles
}

Richard P. Wenzel, MD

Recently I have been reading the works of Major Greenwood (1880-1949), the first professor of vital statistics and epidemiology at the London School of Hygiene and Tropical Medicine. An intelligent, erudite man and prolific author, he is perhaps most celebrated for his writings on the history of epidemiological and statistical thinking. Although the idea of hospital epidemiology and the concept of the infection control sister had its origin in England at the time of Greenwood's death, it is clear that the idea of surveillance is deeply ingrained in English tradition. Greenwood has recorded much of the tradition.

'To begin with, 1986 marks the 900th anniversary of the Domesday Book, a great survey of landholding in England carried out on orders of William the Conqueror. Because the survey was so detailed and was considered to invade into the personal life of the citizens, it received its maudlin sobriquet because it reminded the English of the last judgment: “[William I] sent his men all over England into every shire and had them find out how many honored hides there were in the shire, or what land and cattle the king himself had in the country, or what dues he ought to have in twelve months from the shire. Also, he had a record of what or how much everybody had who was occupying land in England, in land or cattle, and how much money it was worth. So very narrowly did he have it investigated, that there was no single hide nor a yard of land, nor indeed . . . one ox nor one cow nor one pig which was there left out, and not put down in his record."1 Its use for administrative and legal purposes survived for

\footnotetext{
From the Department of Internal Medicine, University of lowa, Iowa City, Iowa.

Address reprint requests to Richard $P$. Wenzel, MD, Southwest 54, General Hospital, Department of Internal Medicine, University of Iowa, Iowa City, IA 52242.
}

centuries. Its purpose, like most "statistics," was to discover the resources available to the leader of the nation. In earlier times, the name statistics was applied to the comparative description of states, what the Germans called "staaten kunde." This system originated with Aristotle, was later cultivated by the Italians, and culminated in German Universities in the 17th and 18th centuries. ${ }^{2}$

In the reign of King Henry VIII, it was correctly reasoned that the best escape from the plague for his highness was to run from it. In order that the king might know when and where the plague had broken out, it was decreed that all burials would be recorded of those dying from plague. ${ }^{3}$ Thus, the first bill of mortality was written in 1532. The clergy were asked also to maintain a registry of all those married and christened. Not until John Graunt's publication of the Bills of Mortality in 1662, however, were the statistics examined. ${ }^{4}$ Graunt (1620-1674), a London merchant without a formal mathematical education, made a number of significant observations, including the high rate of infant mortality, the excess of male births and subsequent equalization, and the higher mortality in towns versus the countryside. The surveillance data had been gathered primarily by elderly women known as the "searchers," and it was Graunt who refined some of the definitions and improved the accuracy of the data. In addition, he devised methods of estimating populations by sampling. Vital statistics had had its birth.

Graunt had no data as to the ages at death nor the number or ages of the living population. Nevertheless, the bills would remain the primary source of national data for almost 200 years. However, in 1837 a new era began with the opening of the general registrar's office. Its first director, William Farr (1807-1883), wanted to tabulate and analyze rates of mortality not only by sex, age, and residence but also by cause. He also improved the nomenclature and classification. According to Greenwood, "Farr 
found medical statistics in such a state that only men of genius, like Graunt, could use them at all without reaching false conclusions, and when he retired from the public service, he left them so organized and arranged that any reasonably intelligent man could draw accurate conclusions from them."5

Greenwood himself was very much inspired by the pioneers, Graunt and Farr, and examined vital statistics of many conditions, including community-acquired pneumonia. ${ }^{6}$ He was particularly interested in the secular trends of mortality and noted the linear relationship of mortality and age and the similarity of death rates between the sexes. Of interest, he noted the apparent higher mortality for patients treated in the hospital compared to those treated outside of the hospital for pneumonia, a disparity which he attributed to the difference (confounding variable) of social class.

As a statistician, Greenwood had studied with the great Karl Pearson (1857-1936), the founder of biometrics. It is of interest that Pearson's closest colleagues were W.F.R. Weldon and Francis Galton. Galton had corresponded frequently with Florence Nightingale, and Ms. Nightingale had discussed the possible sponsorship of a professorship of applied statistics at Oxford with a primary focus on social problems. Galton's reply was negative. ${ }^{7}$ Galton, a geneticist, was a first cousin of the author of evolutionary theory, Charles Darwin, and also stated that he could trace his family tree back to William the Conqueror.

Greenwood, who loved history, the classics especially, old wine-like old ideas, and calculating "small sums," died in 1949. About that time, the growth of hospital epidemiology in England began with Brendon Moore, who developed the idea of the infection control sister. She would be a senior nurse who could advise on proper isolation and infection-control techniques. ${ }^{8}$ Although no school or concept of hospital-wide surveillance followed, a focused, laboratory-based surveillance was noted for particular pathogens. This was quite natural since Great Britain has had a noble history of great bacteriology, and the infectious problems in the hospital are usually addressed by well trained medical microbiologists.

To those of us on the western side of the Atlantic, it may seem curious why there is so little hospital surveillance performed in England, where statistics, epidemiology, and surveillance itself have flourished. Furthermore, didn't Semmelweis use epidemiological principles and surveillance on the obstetrical wards in Vienna to control mortality from puerperal sepsis 150 years ago? Didn't Peter Cruse also show in $1970^{\circ}$ that surveillance and reporting of postoperative wound infection rates lead to a reduction of infections? And what about SENIC? Surveillance was said to be associated with lower nosocomial infection rates. ${ }^{10}$

Perhaps the English would respond that the American programs would improve with a stronger microbiological support. Furthermore, they might say that the roots in microbiology here are strong, the idea of one nurse per 250 beds is extravagant, and there appears to be good infection control with the existing system. ${ }^{11}$ Additionally, we can be patient since there is a hospital epidemiology group at the Communicable Disease Surveillance Center at Colindale that is reassessing the rates of infection, surveillance techniques, and the costs of infection. Such a response, of course, is only speculation, but I do know what Greenwood would say: "if . . . you will try to keep an open mind-a state carefully to be distinguished from an empty mind-and while using by predilection whatever technique, clinical, bacteriological or statistical, is most congenial to you, will both study the general factors of ill health and try to understand the views of others using different methods, then you will gain no applause, but you will contribute to the solution of the problem, perhaps very little, but something." 12

\section{REFERENCES}

1. Hallam EM (ed): Domesday Book. Through Nine Centuries. Thames and Hudson. London, Her Majesty's Stationery Office, 1986, pp 16.

2. Westergaard H: Contributions to the History of Statistics. London, P.S. King \& Sons Ltd., 1932.

3. Greenwood M: History and sources of official vital statistics. Association Special Libraries Information Bureau 1-8, 1932. In The Collected Writings of Major Greenwood, Medical Library, London School of Hygiene and Tropical Medicine.

4. Graunt J: Natural and Political Observations Mentioned in a Following Index and Made upon the Bills of Mortality, 5th ed. 1676 , London, John Martyn.

5. Greenwood M (ed): Epidemics and Crowd Diseases: An Introduction to the Study of Epidemiology. London, Williams and Norgate Ltd., 1935, pp 51.

6. Greenwood M, Candy RH: The fatality of fractures of the lower extremity and of lobar penumonia. A study of hospital mortality rates 1751-1901. J Roy Stat Soc 1911; 74:365-405.

7. Greenwood M (ed): Some British Pioneers of Social Medicine. London, Oxford University Press, 1948.

8. Osterman CA: The infection control practitioner, in Wenzel RP (ed): Handbook of Hospital Acquired Infections. Boca Raton, CRC Press, 1981, pp 19-32.

9. Cruse PJE: Surgical wound sepsis. Can Med Assoc J 1970; 102:251-258.

10. Haley RW, Culver DH, White JW, Morgan WM, Emori TG, Dunn VP, Hooton TM: The efficacy of infection surveillance and control programs in preventing nosocomial infections in US hospitals. Am J Epidemiol 1985; 121:182-205.

11. Meers PD, Ayliffe GAJ, Emmerson AM, Leigh DA, Mayon-White RT, Mackintosh CA, Stronge JL: Report on the national survey of infection in hospital, 1980. J Hosp Infect 1981; 2(suppl).

12. Greenwood M: Old wine in new bottles. St. Thomas Hospital Gazette 1938; 36:398-407. 